세가지 도축 종료 시점을 공변량으로 하는 한우 도체형질에 대한

\author{
유전능력 분석모형 \\ 최연호*·윤호백*·최성복*·정흥우**
}

축산연구소 한우시험장, 강원도 평창군*, 천안 연암축산원예 대학, 충청남도 천안시 **

\title{
Genetic Analysis of Carcass Traits in Hanwoo with Different Slaughter End-points
}

\author{
Y. H. Choy*, H. B. Yoon*, S. B. Choi* and H. W. Chung** \\ Hanwoo Experiment Station of National Livestock Research Institute, Pyongchang* \\ Department of Animal Husbandry, Chonan Yonam College of Agriculture, Chonan **
}

\begin{abstract}
적 요
한우의 성장과 도체형질에 대한 유전능력 평가모형을 개발하기 위해 4 가지 공분산 모형을 적용하 여 후대검정에 공시된 수소와 거세 수소의 자료에 대한 표현형 및 유전자형에 대한 분산-공분산을 추정하였다. 4 가지 모형은 검정소와 검정차수로 구분한 동기그룹의 고정효과와 임의효과인 종모우 효 과로 구성된 부계 반형매 모형을 적용하였다. 도체형질에 대해서는 4 가지 공변량을 추가하였는데 모 형 1 에는 도축일령의 1 차식효과를, 모형 2 에는 도축연령의 1 차와 2 차식 효과를 사용하였고, 모형 3 에 는 절식체중을 모형 4 에는 등지방두께를 각기 1 차식 공변량으로 사용하였다. 도축일령의 2 차식 효과 는 유의적이지 않았으나 도축일령에 대한 회귀로 인하여 4 개 도체형질에 대한 유전 분산-공분산 성 분에 큰 차이를 보였다. 도축 일령을 공변량으로 하였을 때 등지방 두께, 등심단면적, 도체중, 근내지 방도와 도체율에 대한 유전력은 각기 $0.34,0.22,0.24,0.42,0.18$ 로 추정되었다. 도체중과 다른 도체형 질간에는 정 $(+)$ 의 유전상관을 보였으나, 등지방 두께와 등심단면적, 그리고 근내지방도와 도체율 간에 는 낮은 부(-)의 유전상관을 보였다. 절식체중에 대한 회귀는 도체중에 대한 유전분산과 타 도체형 질과의 유전 공분산을 감소시켰으며, 등지방 두께에 대한 회귀는 등심단면적에 대한 유전분산과 등심 단면적과 도체중 간의 유전 공분산을 증가시켰다. 절식체중이나 등지방두께를 공변량으로 한 모형으 로부터 추정된 분산-공분산 성분은 도축 일령을 공변량으로 했을 때와 상이한 구조를 보였는데, 이 들 두 가지 공변량은 골격-근육-지방조직으로 구성되는 신체 부분적 발달 정도와 관련이 있는 것 으로 판단된다.
\end{abstract}

(Key words : Hanwoo, Heritability, Correlation, Carcass traits, Differential growth)

\section{I . INTRODUCTION}

Korean beef price at slaughterhouses are determined by yield grade and quality grade of cold carcasses. Yield grade is an index comprising carcass weight, rib eye area and back fat thick- ness measurements at 12 13th rib. Quality grade is an integrated score considering subjective score in intramuscular fat, fat and meat color, carcass maturity, and texture. Major determinant of quality score is marbling score. Meat-grading technicians are subjectively grading meat quality

Corresponding author:Y. H. Choy, Pyongchang-gun Doahm-myon Chahang-ri 268, Kangwondo, Republic of Korea 232-952, Tel. : +82-33-330-06223 Fax :+82-33-330-0660 E-mail : ychoy000@ hanmail. net 
on the basis of amount and distribution of intramuscular fat in rib eye area.

Evaluation of genetic potential in carcass traits is in controversy. Three main focuses in modeling carcass characteristics are estimating breeding values at constant age (Hirooka et al., 1996), constant carcass weight, constant marbling score or constant back fat thickness (Lee et al., 2000; Shank et al., 2001). Proper assessment of the relationship of models in terms of genetic variances and covariances are required in effective selection of evaluation models for carcass characteristics (Cundiff et. al., 1969). If the industrial focus were on beef quality rather than yield score, then evaluation of carcass merit on constant weight basis would be preferred. However, a body compositional change in later stages of life is more likely to relate with mature size and maturing rate (Choy et al., 2002), body weight or age may not account for the physiological status of individual animals.

The purpose of this research was to estimate the phenotypic and genetic relationships (covariances) between carcass traits when those were regressed on age of animal at slaughter, cold carcass weight or back fat thickness of Hanwoo carcasses.

\section{MATERIALS AND METHODS}

\section{Animals}

A total of 1,349 records of Hanwoo steer calves on progeny test slaughtered from 1998 to 2002 were analyzed. These data represented two test stations (Namwon and Daekwanryung branches of National Livetock Research Institute) on 9 progeny tests from 175 sires on test nationwide. Bull calves born from performance tested sires by aritificial insemination after weaning at around six months of ages were purchased from individual farms. Test animals at two test station are all castrated after shipment and fed the same feedstuff, rice straw and concentrates mixed at a feedmill of National Agricultural Cooperatives Federation (NACF; formerly National Livestock Cooperatives Federation), by 24 months of age when they are slaughtered for carcass evaluations. For assigning carcass characteristics, all the animals on progeny test were slaughtered at the end of performance test (24 months of age). Animals were sent to Seoul slaughterhouse of NACF and the carcass yield and quality values were evaluated by trained practitioners of Animal Products Grading Service station. Carcass yield grades were determined by an index combining weight of cold carcass, back fat thickness and eye muscle area (rib eye area) right behind the last thoracic vertebrae. Quality grades were determined by marbling scores (1 7: 1 is no intramuscular fat particle found, and 7 is abundant) subjectively evaluated by the practitioners considering the color of loin eye muscle and intramuscular fat, tenderness, texture, maturity, and hardness of fat.

\section{Statistical Analyses}

Basic statistical model included contemporary group defined as the same test period and the same test station as fixed effects. Sires assumed to have paternal half-sib relationships among each other were included in the model and considered as a random effect. Body weights measured at 6 (WT6), 12 (WT12), 18 (WT18) and 24 months of age (WT24) were also evaluated using the following model (Model 1) and the (co)variance structure was estimated.

For carcass trait analyses, following linear covariates were put into the basic model 1 (Model 2): 1) Age at slaughter in its first order and 2) in first and second order, 30 body weight at slaughter, and 3) back fat thickness. Carcass traits studied were carcass weight (CWT), dressing percentage (DP), back fat thickness (BFT), rib eye 
area (REA), and marbling score (MS).

\section{Model 1 (for body weights) :}

$$
\mathrm{y}_{i j k l}=\mu+\text { Station }_{i}{ }^{*} \text { Test }_{j}+\text { Sire }_{k}+\mathrm{e}_{i j k l}
$$

Model 2 (for carcass characteristics) :

$$
\mathrm{y}_{i j k l}=\mu+\text { Station }_{i}^{*} \text { Test }_{j}+\text { Sire }_{k}+\beta \mathrm{X}_{i j k l}+\mathrm{e}_{i j k l}
$$

Where, $\mathrm{y}_{i j k l}$ is the body weight (carcass trait) of $l$ th calf out of sire $k$ fed at station $i$ and on test $j$ and $\mathrm{e}$ is the residual effect of that trait. $\beta$ is the regression coefficient of trait value on each covariate. Considering ages at slaughter as covariates, for two models, one with the linear and quadratic terms of ages and the other with only linear term were fitted.

Analyses of variance components were run with generalized linear model (GLM) procedure of SAS (1990) with multivariate application assuming paternal half-sib relationships between sires and using type III sum of squares (Becker, 1984).

\section{RESULTS AND DISCUSSION}

Effect of contemporary group effects and sires on body weights were all significant. Coefficients of variation of body weights at $6,12,18$, and 24 months of ages were 16.3, 11.6, 9.9, and $9.4 \%$, respectively. The genetic and residual (co) variances between body weights are summarized in Table 1. There exist considerable genetic variances for these weight traits and covariances between body weights. Table 2 shows the genetic and phenotypic (co)variance ratios and correlations between growth traits. Heritability of body weight at six months of age was estimated high enough to ensure fast genetic progress by selection. Genetic and phenotypic correlations between these body weights were also high to make indirect selection on weight traits earlier in life and to make generation intervals shorter.

Genetic and residual (co)variances for (between) carcass traits are summarized in Table 3. Linear effect of age at slaughter was significant for carcass weight, dressing percentage and marbling score and not for back fat thickness and rib eye area. Linear and quadratic effects of age at slaughter were not significant for all the carcass traits estimated. Linear effect of body weight at slaughter was significant for all the carcass traits except dressing percentage. Linear effect of back fat thickness was significant for all the carcass traits, i.e. carcass weight, dressing percentage, rib eye area and marbling score. Four models which have differences in covariate terms changed the variance-covariance structure of carcass traits. Genetic variance of back fat thickness was not changed by different covariates in the model while residual variance of it was decreased a little by covariating on body weight at slaughter than on age at slaughter (Table 3). Genetic variances of rib eye area and carcass weight

Table 1. Genetic (residual, in parentheses) variance component estimates (diagonals), genetic covariances (above diagonals) and residual covariances (below diagonals) between body weights

\begin{tabular}{ccccc}
\hline Traits $^{1)}$ & WT6 & WT12 & WT18 & WT24 \\
\hline \hline WT 6 & $607.5(610.9)$ & 364.3 & 310.5 & 368.4 \\
WT12 & 542.4 & $363.8(994.4)$ & 347.6 & 448.3 \\
WT18 & 588.2 & $1,069.7$ & $507.7(1,707.8)$ & 610.9 \\
WT24 & 601.9 & $1,148.1$ & $1,715.2$ & $805.5(2,696.0)$ \\
\hline
\end{tabular}

${ }^{1)}$ WT6 : body weight at 6 months of age, and so on. 
Table 2. Estimates of heritabilities (diagonals) and genetic (above diagonals) and phenotypic correlations (below diagonals) between body weights

\begin{tabular}{ccccc}
\hline Traits $^{1)}$ & WT6 & WT12 & WT18 & WT24 \\
\hline \hline WT6 & 0.50 & 0.77 & 0.56 & 0.53 \\
WT12 & 0.70 & 0.27 & 0.81 & 0.83 \\
WT18 & 0.55 & 0.82 & 0.23 & 0.96 \\
WT24 & 0.47 & 0.73 & 0.84 & 0.23 \\
\hline 1) WT6: body & weight at 6 months
\end{tabular}

were decreased dramatically by covariating on body weight at slaughter than by covariating on ages at slaughter in first or second order by covariating on back fat thickness. Genetic variance of marbling score was decreased a little by covariating on slaughter weight than by covariating on ages or on back fat thickness. Genetic variance of dressing percentage was decreased by covariating on back fat thickness than on ages or on slaughter weight. Regressing rib eye area and carcass weight on back fat thickness increased the genetic variances slightly and decreased genetic variance of dressing percentage while residual variance of carcass weight was decreased a little without any significant changes in genetic or residual variances of marbling score and dressing percentage. These changes in variance components were reflected on the heritability estimates.

Changes in carcass trait parameters, genetic and phenotypic (co)variance ratios and correlations are summarized in Table 4. Heritability estimates of marbling score were moderate to high (0.41-0.42) from all models that ensure effective selection to make genetic changes in this trait. Our heritability estimates were similar to the estimates by Lee et al. (2000). However, they estimated genetic and residual variances in Korean Native
Cattle (Hanwoo) to be some less than our estimates. This might have been due to scalar differences in MS such that they used 1-5 scores while we used 1-7 scores. Back fat thickness and carcass weight were also moderately heritable to apply selection effective for improving yield grades of Hanwoo. Covariate of age at slaughter in first order was compared with the other forms of covariates. Quadratic effect of age at slaughter did not make any significant change in (co) variance structure when it was added to its linear form of covariate. However, slaughter weight decreased the genetic and residual variance of carcass weight and rib eye area dramatically, which changed the heritability estimates and phenotypic and genetic correlation between these traits and others. This resulted in slightly smaller heritability estimates of rib eye area and carcass weight and slightly larger heritability estimates of back fat thickness. Similar trend was found by Lee et al. (2000) for rib eye area or by Cundiff et al. (1969) who found significant changes in the variation of retail cuts by covariating on carcass weight. Slaughter weight covariate also strengthened both phenotypic and genetic relationships between carcass weight and dressing percentage and between back fat thickness and rib eye area (negative) or carcass weight (positive). However, slaughter weight halved the phenotypic and genetic relationships (positive) between rib eye area and carcass weight. Regression on back fat thickness increased the heritability estimates of rib eye area and carcass weight without any recognizable changes in those of marbling score or dressing percentage. Positive even if low genetic correlation between marbling score and yield grade determining traits (back fat thickness, rib eye area and carcass weight) ensures that both yield and quality grades of Hanwoo carcasses can be objected without negative selection response between these as were the results of other researchers (Baik et al., 2003; Lee 
Table 3. Genetic (residual, in parentheses) variance component estimates (diagonals), genetic covariances (above diagonals) and residual covariances (below diagonals) between carcass traits with different slaughter end points

\begin{tabular}{|c|c|c|c|c|c|}
\hline Traits $^{1)}$ & BFT & REA & CWT & MS & $\mathrm{DP}$ \\
\hline \multicolumn{6}{|c|}{ covariate: age at slaughter $\left(1^{\text {st }}\right.$ and $2^{\text {nd }}$ order $)$} \\
\hline BFT & $0.043(0.081)$ & -0.074 & 1.009 & 0.018 & 0.107 \\
\hline REA & 0.256 & $16.8(58.5)$ & 48.227 & 0.468 & 0.882 \\
\hline CWT & 3.453 & 123.285 & $289.6(934.2)$ & 3.807 & 5.184 \\
\hline MS & 0.040 & 1.806 & 6.505 & $1.41(1.93)$ & -0.087 \\
\hline DP & 0.095 & 3.803 & 22.218 & 0.318 & $0.90(4.14)$ \\
\hline \multicolumn{6}{|c|}{ Covariate: age at slaughter $\left(1^{\text {st }}\right.$ order $)$} \\
\hline BFT & $0.042(0.081)$ & -0.072 & 1.003 & 0.019 & 0.104 \\
\hline REA & 0.256 & $16.8(58.5)$ & 48.165 & 0.466 & 0.876 \\
\hline CWT & 3.451 & 123.178 & $289.7(933.4)$ & 3.817 & 5.161 \\
\hline MS & 0.040 & 1.804 & 6.498 & $1.40(1.93)$ & -0.080 \\
\hline DP & 0.096 & 3.804 & 22.201 & 0.315 & $0.87(4.14)$ \\
\hline \multicolumn{6}{|c|}{ covariate: weight at slaughter } \\
\hline BFT & $0.044(0.071)$ & -0.149 & 0.686 & 0.009 & 0.100 \\
\hline REA & -0.112 & $9.8(45.0)$ & 4.850 & -0.020 & 0.886 \\
\hline CWT & 0.551 & 17.409 & $30.6(108.3)$ & 0.273 & 4.492 \\
\hline MS & 0.022 & 1.209 & 1.816 & $1.35(1.92)$ & -0.080 \\
\hline DP & 0.087 & 3.536 & 20.313 & 0.321 & $0.90(4.15)$ \\
\hline \multicolumn{6}{|c|}{ Covariate: back fat thickness } \\
\hline REA & - & $19.4(58.0)$ & 64.547 & 0.684 & 1.135 \\
\hline CWT & - & 114.447 & $338.5(809.8)$ & 4.313 & 3.214 \\
\hline MS & - & 1.766 & 5.467 & $1.39(1.93)$ & -0.108 \\
\hline DP & - & 3.572 & 18.888 & 0.290 & $0.71(4.05)$ \\
\hline
\end{tabular}

et al., 2000; Pariacote et al., 1998; Shanks et al., 2001). Furthermore, genetic relationships of marbling score with back fat thickness, rib eye area or carcass weight were almost zero when these variables were regressed on slaughter weight, which made certain that differential growth at later stages in life had been the major source of variation. Negative genetic and phenotypic correla- tions between back fat thickness and rib eye area were found as was the result of Pariacote et al. (1998) with American Shorthorn data. Even though the relationships were not as strong as in Shorthorn population, this negative relationship is desirable to improve meat yield grade without any adverse effect on other traits.

Body weight at 24 months age was moderately 
Table 4. Estimates of heritabilities (diagonals), genetic correlations (above diagonals) and phenotypic correlations (below diagonals) between carcass traits with different slaughter end points as linear covariates

\begin{tabular}{|c|c|c|c|c|c|}
\hline Traits $^{1)}$ & BFT & REA & CWT & MS & DP \\
\hline \multicolumn{6}{|c|}{ covariate: age at slaughter(1st and 2 nd order) } \\
\hline BFT & 0.34 & -0.09 & 0.29 & 0.08 & 0.55 \\
\hline REA & 0.06 & 0.22 & 0.69 & 0.10 & 0.23 \\
\hline CWT & 0.36 & 0.56 & 0.24 & 0.19 & 0.32 \\
\hline MS & 0.09 & 0.14 & 0.16 & 0.42 & -0.08 \\
\hline DP & 0.26 & 0.24 & 0.35 & 0.06 & 0.18 \\
\hline \multicolumn{6}{|c|}{ covariate : age at slaughter(1st order) } \\
\hline BFT & 0.34 & -0.09 & 0.29 & 0.08 & 0.54 \\
\hline REA & 0.06 & 0.22 & 0.69 & 0.10 & 0.23 \\
\hline CWT & 0.36 & 0.56 & 0.24 & 0.19 & 0.32 \\
\hline MS & 0.09 & 0.14 & 0.16 & 0.42 & -0.07 \\
\hline DP & 0.25 & 0.24 & 0.35 & 0.06 & 0.17 \\
\hline \multicolumn{6}{|c|}{ covariate : weight at slaughter } \\
\hline BFT & 0.38 & -0.23 & 0.59 & 0.04 & 0.50 \\
\hline REA & -0.10 & 0.18 & 0.28 & -0.01 & 0.30 \\
\hline CWT & 0.31 & 0.26 & 0.22 & 0.04 & 0.86 \\
\hline MS & 0.05 & 0.09 & 0.10 & 0.41 & -0.07 \\
\hline DP & 0.25 & 0.27 & 0.94 & 0.06 & 0.18 \\
\hline \multicolumn{6}{|c|}{ covariate : back fat thickness } \\
\hline REA & & 0.25 & 0.80 & 0.13 & 0.31 \\
\hline CWT & & 0.60 & 0.29 & 0.20 & 0.21 \\
\hline MS & & 0.15 & 0.16 & 0.42 & -0.11 \\
\hline DP & & 0.25 & 0.30 & 0.05 & 0.15 \\
\hline
\end{tabular}

\footnotetext{
${ }^{1)}$ Back fat thickness (BFT, cm), rib eye area (REA, $\mathrm{mm}^{2}$ ), carcass weight (CWT, $\mathrm{kg}$ ), dressing percentage (DP), marbling score (MS).
}

heritable. But the correlations, both genetic and phenotypic, were high with body weights at later stages in life and were medium and positive with body weights while growing. This differential growth pattern typical in most animal species is reflected on the relationships between carcass compositional parameters. Variation in carcass weight as well as slaughter weight comprises three major components of body constituents: bones, muscles and fat covers. Part-whole relationships between slaughter weight and back fat thickness or between slaughter weight and rib eye area make genetic variation in each component of body constituents more easily visible. In other words, as differences in body weight of later fattening stage in life is more of the changes in fat deposition than muscle growth, greater degree of genetic relationship between 
carcass weight and back fat thickness and lesser degree of genetic relationship between carcass weight and rib eye area had been revealed when these variables were regressed on slaughter weight. This was also verified by much increase in the genetic and phenotypic correlation (0.86 and 0.94 , respectively) between carcass weight and dressing percentage when regressed on slaughter weight (Table 4). This is due mainly to the decrease in genetic and residual variances in carcass weight by regressing on the average slaughter weight. However, the only visible change in the relationship with marbling score was with carcass weight when those were regressed on slaughter weight.

When the carcass variables were regressed on back fat thickness, variance and covariance components were not changed from when those were regressed on ages at slaughter. However, genetic variance of carcass weight was increased and residual variance of that decreased. Covariances between rib eye area and carcass weight, between rib eye area and marbling score and between rib eye area and dressing percentage were increased while residual variance between these were decreased a little resulting in increased genetic correlations. That is, slaughter weight cleared out the variation due to muscle growth and fat deposition at the same time because it decreased the genetic and residual variance of carcass weight and because it decreased the genetic and residual covariance between rib eye area and carcass weight. Back fat thickness, on the other hand, cleared out the variation due to fat deposition only because this increased the genetic variance of carcass weight and because genetic covariance between rib eye area and carcass weight. Another typical changes in covariance structure is found between carcass weight and dressing percentage where genetic covariance was decreased at higher rate (Table 3) than residual variance showing lower genetic and phenotypic correlations between them(Table 4). These changes by regressing on back fat thickness are comparable to the changes by regressing on slaughter weight which shifted (co)variance structure counter to each other regressors.

The results of this study agreed well with those of Cundiff et al. (1969) in that for overall body growth, carcass trait evaluation at age constant basis was effective but less effective than that for differential growth of body parts, at body weight constant basis. However, for the genetic progress in favor of the size of rib eye area and marbling score at the same time, carcass evaluation at constant back fat thickness seems advantageous because of favorable positive genetic relationship between these two target traits and increased genetic variances and covariances of (between) carcass traits.

\section{ABSTRACT}

Data from Hanwoo steers and bull calves were analyzed to see the phenotypic and genetic relationships between carcass traits from four different covariance models. Four models fit test station and test period as fixed effect of contemporary group and sire as random effect assuming paternal half-sib relationships among animals. Each model fits one of linear covariate (s) of different slaughter end points-age at slaughter in the first order, age at slaughter in the first and second order, slaughter weight or back fat thickness at 12-13th rib of cold carcass. Age at slaughter in its second order was not significant. Age at slaughter accounted for significant amount of genetic variances and covariances of carcass traits. Heritability estimates of back fat thickness, rib eye area, carcass weight, marbling score and dressing percentage were $0.34,0.22$, $0.24,0.42$ and 0.18 , respectively at constant age basis. The genetic correlation between carcass weight and the other variables were all positive 
and low to high in magnitude. Genetic correlations between back fat thickness and rib eye area and between marbling score and dressing percentage were low but negative. Variance and covariance structure between these traits were shifted to a great extent when these variables were regressed on slaughter weight or on back fat thickness. These two covariates counteracted to each other but they adjusted each carcass variable or their interrelationship according to differential growth of body components, bone, muscle and fat. Slaughter weight tended to decrease genetic variances and covariances of carcass weight and between component traits and back fat thickness tended to increase those of rib eye area and between rib eye area and carcass weight.

(Key words: Hanwoo, Heritability, Correlation, Carcass traits, Differential growth)

\section{ACKNOWLEDGEMENT}

Authors wish to notify that this study was projected and funded by Yonam College of Agriculture and partly by the industry cooperative research project of NLRI (National Livestock Research Institute) entitled "Genetic Evaluation Model Development with On-farm Performance Test Records". And we also thank NACF (National Agricultural Cooperatives Federation), Korea and NLRI (National Livestock Research Institute), Korea for their endeavors in data collection and management of Hanwoo breeding population.

\section{REFERENCES}

1. Baik, D. H., Hoque, M. A., Park, G. H., Park, H. K., Shim, K. S. and Chung, Y. H. 2003. Heritabilities and genetic correlation, and sire and environment effects on meat production potential of Hanwoo cattle. Asian-Aus. J. Anim. Sci. 16:1-5.

2. Becker, W. A. 1984. Manual of quantitative genetics. Academic Enterprises. Pullman, WA, USA.

3. Choy, Y. H., Jeon, G. J., Kim, T. H., Choi, B. H., Cheong, I. C., Lee, H. K., Seo, K. S., Kim, S. D., Park, Y. I. and Chung, H. W. 2002. Genetic analyses of carcass characteristics of crossbred pigs: Cross between Landrace sows and Korean Wild boars. Asian-Aus. J. Anim. Sci. 15:1080-1084.

4. Cundiff, L. V., Gregory, K. E., Koch, R. M. and Dickerson, G. E. 1969. Genetic variation in total and differential growth of carcass components in beef cattle. J. Anim. Sci. 29:233-244.

5. Hirooka, H., Groen, A. F. and Matsumoto, M. 1996. Genetic parameters for growth and carcass traits in Japanese Brown cattle estimated from field records. J. Anim. Sci. 74:2112-2116.

6. Lee, J. W., Choi, S. B., Kim, J. S., Keown, J. F. and Van Vleck, L. D. 2000. Parameter estimates for genetic effects on carcass traits of Korean Native Cattle. J. Anim. Sci. 78:1181-1190.

7. Pariacote, F., Van Vleck, L. D. and Hunsley, R. E. 1998. Genetic and phenotypic parameters for carcass traits of American Shorthorn beef cattle. J. Anim. Sci. 76:2584-2588.

8. SAS Institute. 1990. SAS/STAT User's guide. V.6, $4^{\text {th }}$ Ed. Cary, NC, USA.

9. Shanks, B. C., Tess, M. W., Kress, D. D. and Cunningham, B. E. 2001. Genetic evaluation of carcass traits in Simmental-sired cattle at different slaughter end points. J. Anim. Sci. 79:595-604.

(접수일자 : 2005. 5. 2. / 채택일자 : 2005. 8. 3.) 